\title{
A Escola Pública, Universal e Gratuita
}

\author{
ANÍSIO TEIXEIRA
}

\section{MOVIMENTO DE EMANCIPAÇÃo POPULAR PELA EDUCAÇÃO}

\begin{abstract}
No mês de maio último, reuniram-se em Lima, convocados pela Organização dos Estados Americancs (a antiga União Pan-Americana), os representantes dos Governos nacionais do nosso continente. Estes representantes não eram ministros da Fazenda, nem ministros do Exterior. Eram ministros da Educação. O tema da reunião não era a política exterior nem a política econômica ou financeira, e sim a política educacional. E em política educacional, não se debateram os problemas do ensino secundário, nem do ensino superior; mas, do ensino primário.
\end{abstract}

A despeito do caráter de que quase sempre se revestem essas reuniões internacionais, do seu ar tantas vêzes irremediàvelmente convencional, os que lá estiveram sentiram, em mais de um momento, que algo de histórico se processava na evolução política das Américas. O drama de 59 milhões de analfabetos, inclusive os de idade escolar, da América latina e de outros tantos milhões de semi-alfabetizados, em suas escolas primárias de dois e três anos de estudos e de dois e três turnos por dia letivo, repercutia nos salōes do edifício do Congresso Nacional de Lima, onde se realizou a reunião interamericana, como um trovejar, talvez ainda distante, mas já suficientemente audivel, da consciência popular dos povos americanos. Dir-se-ia que, despertados afinal para as suas reivindicações fundamentais, eram os povos do Continente que convocavam aquêle conclave, para a fixação de medidas destinadas a assegurar-lhes o direito dos direitos: uma escola primária, eficiente e adequada, para todos.

E por isto mesmo - a despeito das vozes, muito nossas conhecidas, dos que ainda julgam possível reduzir a educação popular, na América latina, à mistificação das escolas primárias de tempo parcial e de curtos períodos anuais - a assembléia decidiu, com a afirmação de princípios da "Declaração de Lima", por uma escola primária de seis anos de curso e dias letivos completos.

No mesmo ano, em que os governos americanos, reunidos em assembléia, fizeram tal declaração histórica, o Estado de São Paulo, isto é, o Estado-líder da Federação brasileira, convoca o seu primeiro Congresso de Ensino Primário. 
Sabemos que um fato não está ligado a outro. Mas, a coincidência pode ser tida como significativa: a mesma obscura fôrça, que está movendo a consciência coletiva, parece haver atuado para a escolha do tema da reunião de Lima, como para a reunião, no ano passado, do Congresso de Professôres Primários, de Belo Horizonte, e para êste Congresso do Ensino Primário, तe São Paulo, ora aqui reunido, em Ribeirão Prêto. Presumo que se trata de um sinal, um grande sinal, de amadurecimento da consciência pública do país.

Por isso estou seguro de que não estamos aqui para discutir, como é tanto do nosso gôsto, a educação dos poucos, a educação dos privilegiados mas, a educação dos muitos, a educação de todos, a fim de que se abra para - nosso povo aquela igualdade inicial de oportunidades, condição mesma para a sua indispensável integração social.

Não se pode ocultar ser algo tardio êsse movimento de emancipação educacional ou de emancipação pela educação.

Desde a segunda metade do século dezenove, quando não antes, as nações desenvolvidas haviam cuidado da educação universal e gratuita. Cogitando de realizá-la, agora, em época que, na verdade, já se caracteriza por outras agudas reivindicações sociais, de mais nítido ou imediato caráter econômico, corremos o risco de não poder configurar com a necessária clareza os objetivos da emancipação educacional. E que, no caso, trata-se ainda de algo que já nos devia ter sido dado, que já há muito fôra dado a outros povos, de cujas atuais asp.rações queremos partilhar. Estas novas aspirações, mais fortemente motivadas pelos imperativos da época, sobrepõem-se às aspirações educacionais e de certo modo as desfiguram, criando, pela falta de sincronismo, especiais dificuldades para o seu adequado planejamento.

A relativa ausência de vigor de nossa atual concepção de escola pública e a aceitação semi-indiferente da escola particular foram e são, ao meu ver, um dos aspectos dessa desfiguração generalizada de que sofre a política educacional brasileira, em virtude do anacronismo do nosso movimento de educação popular.

Como os povos desenvolvidos já não têm hoje (salvo mínimos pormenores) o problema da criação de um sistema, universal e gratuito, de escolas públicas, porque o criaram em período anterior, falta-nos, em nosso irremediável e crônico mimetismo social e político, a ressonância necessária para um movimento que, nos parecendo e sendo de fato anacrônico, exige de nós a disciplina difícil de nos representarmos em outra época, que não a atual do mundo, e de pautarmos os nossos planos, descontando a decalagem histórica com a necessária originalidade de conceitos e planos, para realizar, hoje, em condições peculiares outras, algo que o mundo realizou em muito mais feliz e propício instante histórico.

Se nos dermos ao trabalho de voltar atrás e ouvir as vozes dos que ainda no curso do século dezenove, no mundo, e, entre nós, imediatamente antes e logo depois da República, definiram (mesmo então com atraso) os objetivos do movimento de emancipação educacional, ficaremos surpreendidos com a intensidade do tom de reivindicação social, que caracterizava o movimento. E que a escola era, na época, a maior e mais clara con- 
quista social. E hoje, o anseio por outras conquistas, mais pretensiosas e atropeladas, a despeito de não poderem, em rigor, ser realizadas sem a escola básica, tomaram a frente e subalternizaram a reivindicação educativa primordial. Tomemos, com efeito, ao acaso, as expressões de um dêsses pioneiros continentais da educação popular - por um conjunto de circunstâncias, o primeiro: HORACE MANN. O grande batalhador da educação pública e universal, nos Estados Unidos, que no continente só encontra paralelo contemporâneo em SARMIENTO, na Argentina, considerava a "escola pública" - a escola comum para todos - a maior invenção humana de todos os tempos. E em seu relatório ao Conselho de Educação de Boston, assim falava, há cento e oito anos (1848):

"Nada por certo, salvo a educação universal, pode contrabalançar a tendência à dominação do capital e à servilidade do trabalho. Se uma classe pôssui tôda a riqueza e tôda a educação, enquanto o restante da sociedade é ignorante e pobre, pouco importa o nome que dermos à relação entre uns e outros: em verdade e de fato, os segundcs serão os dependentes servis e subjugados dos primeiros. Mas, se a educação fôr difundida por igual atrairá ela, como a mais forte de tôdas as fôrças, posses e bens, pois nunca aconteceu e nunca acontecerá que um corpo de homens inteligentes e práticos venha a se conservar permanentemente pobre...

"A educação, portanto, mais do que qualquer outro instrumento de origem humana, é a grande igualadora das condições entre os homens - a roda de equilíbrio da maquinaria social... Dá a cada homem a independência e os meios de resistir ao egoismo dos outros homens. Faz ma:s do que desarmar os pobres de sua hostilidade para com os ricos: impede-os de ser pobres".

Era com êste espírito que se pregava a escola pública em 1848. Já não era o iluminismo ou a "ilustração", filosôficos, do século dezoito, mas todo o utifitarismo de uma doutrina de igualdade social pela educação. Já não era o puro romantismo individualista, tão vivo ainda, aliás, por todo o século dezenove, a crer, ainda com SPENCER, que o devido ao indivíduo era só a liberdade, no sentido negativo de não interferência - daí não ser essencial ou ser até ilícito dar-lhe o Estado educação... - mas a doutrina positiva de que a liberdade sem educação, isto é, sem o poder que o saber dá, era uma impostura e um lôgro...

Obrigatória, gratuita e universal, a educação só poderia ser ministrada pelo Estado. Impossível deixá-la confiada a particulares, pois êstes sòmente podiam oferecê-la aos que tivessem posses (ou a "protegidos") e daí operar antes para perpetuar as desigualdades socia:s, que para removê-las. A escola pública, comum a todos, não seria, assim, o instrumento de benevolência de uma classe dominante, tomada de generosidade ou de mêdo, mas um direito do povo, sobretudo das classes trabalhadoras, para que, na ordem capitalista, o trabalho (não se trata, com efeito, de nenhuma doutrina socialista,

(1) Annual Report cn Education, Boston, Rand \&6 Avery, 1848, pp. 668-69. 
mas do melhor capitalismo) não se conservasse servil, submetido e degradado, mas, igual ao capital na consciência de suas reivindicações e dos seus direitos.

A escola pública universal e gratuita não é doutrina especificamente socialista, como não é socialista a doutrina dos sindicatos e do direito de organização dos trabalhadores, antes são êstes os pontos fundamentais por que se afirmou e possivelmente ainda se afirma a viabilidade do capitalismo ou c remédio e o freio para os desvios que o tornariam intolerável.

A sobrevivência do capitalismo, em grande parte do mundo, não se explica senão por êstes dois recursos ou instrumentos de defesa contra a desigualdade excessiva que o capitalismo provocaria e provoca, sempre que faltem ao povo escola pública e sindicato livre.

Por que, então, faltou e falta ao Brasil a consciência precisa de que, antes de qualquer outra reivindicação, cabe-lhe reivindicar a escola pública, universal, gratuita e eficiente, e o sindicato, livre e autônomo? Por que, aparentemente, the parece bastar a simulação educacional de escolas de faz-de-conta e os sindicatos de cabresto, que the têm dado, como altíssimo favor de deuses a pobres mortais, governos de despotismo mais ou menos "esclarecido" ou ditaduras falhadas?

\section{DESFIGURAÇÃO DO MOVIMENTO EM VIRTUDE DO SEU ANACRONISMO}

Estou em que uma das razões é o anacronismo a que me referi. Reivindicações sociais, para que a escola iria preparar o povo, amadureceram e estão sendo quiçá atropeladamente satisfeitas, com ou sem fraude aparente e aparente aceleração do processo histórico, impedindo-nos de ver, com a necessária exatidão, quanto nos faltam ainda de reivindicações anteriores e condicionadoras, não satisfeitas no devido tempo e, por isto mesmo, mais difíceis ainda de apreciar e avaliar exata ou adequadamente.

Além da dificuldade inerente ao caráter preparatório ou de "preliminar" condicionante, próprio das reivindicações educacionais, temos a dificuldade do anacronismo que elas ora arrastam consigo e estamos a focalizar, com a sobrecarga, ainda mais grave, de dificuldades específicas decorrentes da aceleração do processo histórico, geral, aceleração sempre mais propícia a reivindicações consumatórias e finalistas, do que a reivindicações preliminares e instrumentais, como são as de educação.

Por todos êsses motivos forçoso é reconhecer que há uma certa perda de contôrno nas mais legítimas reivindicações educacionais, adquirindo o processa de nossa expansão escolar o caráter tumultuário de reivindicações sobretudo de vantagens e privilégios, o que me tem levado a considerá-lo mais como um movimento de dissolução do que de expansão. Foi, com efeito, essa desfiguração da natureza da reivindicação educacional que elevou a matrícula da escola primária, sem lhe dar prédios nem aparelhamento, que multiplicou os ginásios, sem lhes dar professôres, e que faz brotar do papel até escolas superiores e universidades, com mais facilidade do que brotam cogumelos nos recantos mais sombrios e úmidos das florestas... 
Não faltam, entretanto, os que estadeiam certo orgulho ferido ou afetam mesmo um sorriso superior, ao ouvirem aquêles dentre nós que se levantam para afirmar que uma tal expansão, não é expansão mas dissolução... Somos chamados de pessimistas, convocando-nos os nossos Pangloss a ver que o Brasil progride por todos os poros e que o congestionamento, a confusão, a redução dos horários e a falta de aproveitamento nas escolas são outras tantas demonstrações dêsse progresso.

Mas, ao lado dêles, já são numerosas as vozes que se erguem, apreensivas e graves. A verdade é que já se faz difícil ocultar a descaracterização do nosso movimento educacional. Pode-se expandir, pelo simples aumento de participantes, um espetáculo, um ato recreativo, em rigor, algo de consumatório, mas, não se pode expandir, sòmente pelo aumento de participantes, um processo, temporal e espacial, longo e complexo de preparo individual, como é o educativo. E o que vimos fazendo é, em grande parte, a expansão do corpo de participantes, com o congestionamento da matrícula, a redução de horários, a improvisação de escolas de tôda ordem, sem as condições mínimas necessárias de funcionamento. Tudo isto seria já gravíssimo. Mas, pior do que tudo, está a confusão gerada pela aparente expansão, tumultuária, levando o povo a crer que a educação nã̃o é um processo de cultivo de cada indivíduo, mas um privilégio, que se adquire pela participação em certa rotina formalista, concretizada no ritual aligeirado de nossas escolas. Está claro que tal conceito de escola não é explícito, mas decorre do que fazemos. Se podemos desdobrar, tresdobrar e até elevar a quatro os turnos das escolas primárias, se autorizamos ginásios e escolas superiores sem professôres nem aparelhamento, - é que a escola é uma formalidade, que até se pode dispensar, como se dispensam, na processualística judiciária, certas condições de pura forma.

\section{SEguranÇA DA PREgaÇão EDUCACIONAL NO INÍCIO DA REPÚBLICA}

Não é difícil demonstrar que nem sempre assim procedemos, nem sempre assim pensamos. Em verdade, os nossos educadores do início do periodo republicano revelavam uma adequada consonância com os educadores de todo o mundo, no conceituar a educação e no caracterizar o movimento de educação popular, que então se iniciava no país, com o advento da República.

Não posso fugir de citar aqui alguns paulistas, cujas palavras parecem de verdadeiros êmulos dos MANN, SARmiento e Varela, que, mais felizes, lograram realizar em suas nações, na época própria, muito do que pregaram.

Retiro as citações de discursos e relatórios feitos todos antes do início dêste século, ainda no fervor republicano da década última do século dezenove.

Caetano de Campos, Cesário Mota, Gabriel Prestes (para só citar paulistas) aqui irāo nos revelar como era viva e lúcida e quente a convicção democrática da função da escola, na República e em seus primórdios.

"A democratização do poder restituiu ao povo uma tal soma de autonomia, que em todos os ramos de administração é hoje 
indispensável consultar e satisfazer suas necessidades. Já que a revolução entregou ao povo a direção de si mesmo, nada é mais urǵente do que cultivar-lhe o espírito, dar-lhe a elèvação moral de que êle precisa, formar-lhe o caráter, para que saiba querer.

"Dantes pagava a nação os professôres dos principes sob o pretexto de que êstes careciam duma instrução fora do comum para saber dirigí-la. Hoje, o príncipe é o povo, e urge que êle alcance o "self-government" - pois só pela convicção científica pode ser levado, desde que não há que zelar o interêsse de uma família privilegiada.

"A instrução do povo é, portanto, sua maior necessidade. Para - Govêrno, educar o povo é um dever e um interêsse: dever, porque a gerência dos dinheiros públicos acarreta a obrigação de formar escolas; interêsse, porque só é independente quem tem o espírito culto, e a educação cria, avigora e mantém a posse da liberdade.

"E ćbvio que ninguém tolherá aos cidadãos o direito de abrir escolas particulares. Estas não serão, porém, em número suficiente para a população, e nem acessiveis para a grande massa do proletariado.

"Demais, com a exigência do ensino moderno, tais instituições, quando mesmo bem fornidas de um material escolar suficiente, pesarão sôbre a bôlsa do particular de modo tal que, sem remuneração, não poderão ter alunos.

"Bastaria apontar a história do Brasil monárquico para saber quão improgressiva mostrou-se até hoje a família brasileira. Entre a escola primária - irrisória e condenável como era, e já eu disse ao princípio - entre a "escola régia" e a Academia, nenhuma educação dava o Govêrno ao povo. Só os colégios particulares forneciam, aos que podiam pagar, um preparo literário, que visava a matrícula nos cursos superiores.

"Não era por certo com a gramática ensinada desde a primeira idade, e o latim, decorado até à Academia, que o brasileiro poderia conhecer as leis da natureza, nem saber cultivar o solo, nem envolver-se nas indústrias e nas artes.

"Todos nós sabemos o que valiam tais estudos, em que a gramática, o latim, a filosofia... de Barbe, a retórica eram "magna pars". Homens que mal sabiam ler e escrever - em pequena porcentagem - e doutores: eis a única coisa que se podia ser no Brasil." (2)

(2) Todos êsses trechos são da Memória apresentada em 1891 pelo Dr. A. CAETANo dE CAMPos, Diretor da Escola Normal, ao Dr. JORGE TiBIRIçá, então Governador do Estado. 
E três anos depois, em discurso na inauguração da Escola Normal da Praça da República:

"A República foi, pois, a síntese da última fase da nossa civilização.

"Proclamacia a nova forma de govêrno, fêz-se mister realizá-la em tôda sua integridade. A primeira coisa, entretanto, que desde logo feriu os olhos deslumbrados dos que se acharam de posse do novo regime, foi que, com êle, as necessidades da democracia se aumentaram. O que era delegação no antigo sistema, é ação ciireta no novo; as inculpações, que outrora se faziam ao govêrno, recaem agora sôbre o próprio povo; as aptidões requeridas nos seus homens, é êle quem as deve ter porque é êle quem tem de governar, é êle quem tem de dirigir os seus destinos.

"A semelhança do capitão a quem se incumbiu a direção do navio desarvorado em alto mar, o povo viu-se atônito no momento em que tomou o domínio de si mesmo. Reconheceu faltarem-lhe aparelhos para as manobras. Desde logo surgíu forçosa a convicção da necessidade de saber.

" $A$ idéia da instrução então impôs-se.

"É que pràticamente ficou demonstrado o asserto, tão conhecido, do imortal americano: "A democracia sem a instrução será uma comédia, quando não chegue a ser tragédia". E que a República sem a educação inteligente do povo, poderia dar-nos, em vez do govêrno democrático, o despotismo das massas, em vez de ordem, a anarquia, em vez da liberdade, a opressão." (3)

E no mesmo ano de 1894 e na mesma inauguração, como se falasse em uníssono com Cesário MotTta, exclamava Gabriel PREstes, diretor da Escola:

"Que diferença entre essa inépcia dos governos monárquicos e a sincera solicitude pelo interêsse público nos regimens livres! Enquanto no Brasil, em um período de relativa calma, a ação governamental só se manifesta em favor das classes superiores, em França, no meio mesmo da crise revolucionária, institui-se a primeira escola normal em que milhares de alunos, segundo o pensamento da Convenção, deviam preparar-se para levar a todos os cantos da Repú. blica os conhecimentos necessários ao cultivo da inteligência.

"Nos Estados Un:dos, com um ardor ainda não igualado, todos os espíritos ilustres fazem consistir na difusão do ensino o programa de todos os governos, e foi assim que cs Washington, os Madison, os MONROE, os HorÁcios MANN conseguiram lançar os funcamentos da enormíssima prosperidade americana." (4)

(3) CESÁRIo MOTTA, Secretário do Interior, em 1894 - Discurso proferido quando da insuguração da Escola Normal da Praça da República.

(4) Gabriel Prestes - Discurso pronunciado em 2 de agôsto de 1894, como Diretor da Escola Normal da Praça da República, em sua inauguração. 
E já, em 1911, assim falava BUENo DOS REIS JÚNIOR, diretor de Instrução:

"Na época da proclamação da República, bem frisante era o caráter defeituoso e contraproducente do ensino público primário em nosso Estado, pelo que uma das primeiras preocupações dos próceres do govêrno foi promover o aperfeiçoamento dessa instituição.

"Espíritos patrióticos e clarividentes, bem como animados dos mais vivos desejos de progresso, os dirigentes do povo, cônscios de que não pcdia haver aliança possível entre o desenvolvimento de um Estado e o obscurantismo de sua população, trataram, sem perda de tempo, de resolver o problema da instrução pública elementar, problema que se lhes afigurava um dos importantes, senão o mais importante dos seus deveres no momento.

"Efetivamente era urgente dar ao ensino primário uma organização compatível com as necessidades reclamadas pela educação de um povo, para o qual acabava de raiar a aurora da democracia." (5)

A coincidência de ideais com os grandes fundadores dos sistemas de educação pública - universal e gratuita - não podia ser mais completa, nem faltou jamais aos nossos educadores-líderes a consciência perfe:ta do que havia a fazer. $\mathrm{E}$ a escola primária e as escolas normais, que então se implantaram, tinham tôdas as características das escolas da época, sendo, nas condições brasileiras, escolas boas e eficientes. Registravam-se crises no ensino secundário e superior, mas o ensino primário e o normal podiam mais ou mencs suportar honrosos paralelos com o que se fazia em outros países.

\section{INCAPACIDADE DA REPÚBLICA PARA ESTENDER A EDUCAÇÃO A TODOS}

Não bastava, porém, que as escolas não fôssem más. Era necessário que fôssem bastantes. E aí é que falhou inteiramente a pregação republicana, que, muito a propósito, acabamos de evocar quanto a São Paulo.

Sem pretendermos ser exaustivos na perquirição de causas, limitamonos sem falseamento a dizer que nos faltou vigor para expandir a escola a seu tempo, quando os seus padrōes eram bons ou razoáveis ainda, e o processo histórico não havia sofrido os impactos de aceleração dos dias atuais. Um persistente, visceral sentimento de sociedade dual, de governantes e governados, impedia que nos déssemos conta da urgência de expandir a educação do povo, parecendo-nos sempre que bastaria a das elites, já sendo suficientes (senão mais até do que suficientes) as poucas escolas que mantínhamos para o povo e pelas quais nem ao menos tínhamos o cuidado de aperfeiçoar como boas amostras ou modelos.

A dificuldade do regime democrático, com efeito, é que êle só pode ser implantado espontâneamente em situaçōes sociais simples e homogêneas. Tais eram as situações das comunidades relativamente pequenas da primeira

(5) BUENo DOS REIS JÚNIOR, Diretor Geral da Instrução Pública - Relatório apresentadio ao Secretário do Interior em 1911. 
metade ou dois terços primeiros do século dezenove. As minorias diretoras se constituiam, então, como que naturalmente, e podiam subsistir para, de certo modo, impor os seus padrōes às maiorias ainda homogêneas, que lhes aceitavam a liderança.

A simplicidade dessas comunidades, onde todos se conheciam, e a lentidão de seu progresso material ofereciam as condições necessárias para o esfôrço educativo global a ser conduzido pelas minorias condutoras. Tal situação se configura perfeitamente nos Estados Unidos, com a independência e a república. Aos líderes, figuras eminentes e, muitas, aristocráticas, coube a tarefa de orientar, por consentimento de todos, a jovem república.

Quando o desenvolvimento econômico sobreveio, já a estrutura política estava suficientemente formada para suportar o impacto da desordem inevitável da aceleração do progresso material. Não direi que haja faltado à América um período de confusão e de perda de padrões, mas a nação sobreviveu a êle e pôde retomar a segurança de marcha do período anterior, mais simples e homogêneo.

Não foi, porém, isto o que sucedeu conosco. Emergimos do período colonial, sem o sentimento de uma verdadeira luta pela independência, retardando de quase um século a república e embalando-nos com o reino unido, a herança de um príncipe e de uma monarquia, a que não faltaram sequer as ilusões de "império"... Além disto, não chegamos a ser democráticos senão por mimetismo e reflexos culturais de segunda mão. Na realidade, éramos autoritários, senão anacrônicamente feudais. A estrutura de nossa sociedade não era igualitária e individualista, mas escravagista e dual, fundada, mesmo com relação à parte livre da sociedade, na teoria de senhores e dependentes.

A república e, com ela, mais plausivelmente, a democracia, portanto, teriam de abrir caminho, entre nós, mesmo com a "proclamação" de 15 de novembro de 1889 , como um programa revolucionário. Ora, longe de estarmos preparados para isto e muito pelo contrário, dormitamos em todo o período monárquico, sem nenhuma consciência profunda de que, dia viria, em que o povo de tudo havia de participar, sem que para tal o tivéssemos preparado.

A república veio acordar-nos da letargia. Iniciamos, então, uma pregação, que lembra a pregação da segunda metade do século dezenove nas nações então em processo de democratização e da qual nos deram uma amostra as citações que fizemos de educadores paulistas. Tal pregação não chegava, porém, a convencer sequer a elite, supostamente lúcida. Ela continuava a acreditar, visceralmente, que o dualismo de estrutura social, a dicotomia de senhores e súditos, de elite governante e povo dependente e submetido havia de subsistir e de permitir "a ordem e c progresso", mediante a educação apenas de uma minoria esclarecida.

$\mathrm{Na}$ realidađe, ninguém dava crédito aos educadores (nem sequer êles próprios) na sua pregação de educação para todos. Com efeito, os próprios educadores tinham sempre o cuidado de dizer que não era possível, econômicamente, a solução do problema educacional brasileiro... 
Quando mudanças de estrutura social, da ordem da que nos deviam trazer a república e com ela a democracia, se processam efetivamente no seio de um povo, o problema econômico não pode constituir obstáculo à sua real efetivação. Em tal caso, é a estrutura social que se modifica, em virtude, exatamente, de modificação da estrutura econômiça e política.

Isto se daria, no Brasil, se a democracia e a república não fôssem um movimento de cúpula, com simples modificações na minoria governante, enriquec:da ou empobrecida com a entrada de mais alguns elementos das classes relativamente pobres. Não obstante á república, conservamos a nossa estrutura dualista de classe governante e de povo. Seria realmente extravagância que as classes predominantes chegassem, em sua benevolência, ao ponto de se sacrificarem para educar o povo brasileiro...

O apostolado dos educadores tinha, assim, algo de contraditório. Eles próprios admitiam que o sistema de escolas públicas para tôda a população era impossível, e isto mesmo afirmavam, retirando, "avant la lèttre", qualquier eficácia política às suas ungidas palavras.

\section{REVIVESCÊNCIA DEMOCRÁTICA DE 20 A 30}

Quando, na década de 20 a 30 , começou a amadurecer mais a consciência política da nação e se iniciou a batalha pelo voto secreto e livre, esta batalha devia ser acompanhada (uma vez que não precedida) da sua óbvia contrapartida - a educação do povo.

Não se dirá que the tenha faltado completamente êste eco, êste reclamo educacional. Foi, com efeito, nesse período que a idéia de estender a educação a todos começou a medrar. Mas, de que modo?

Até então, os educadores, com a indiferença das classes governantes, vinham mantendo uma escola pública de cinco anos, seguida de um curso complementar. Quando os políticos, entretanto, resolveram tomar conhecimento do problema, forçados pela conjuntura social do Brasil, a primeira revelação de que não thes era possível sentí-lo em sua integridade, mas, apenas, sentir a necessidade de escamoteá-lo, patenteou-se na solução proposta: - reduzir as séries, para atingir maior número de alunos. $\mathrm{E}$ foi exatamente aqui, em São Paulo, em 1920, que houve a tentativa da escola primária de dois anos (!) que, embora combatida e, felizmente, malograda, passou a ser padrão inspirador de outras simplificações da educação brasileira.

Em 1929, considerando a tentativa de dar educação a todos altamente significativa e comêço de uma consciência democrática, que iria prosseguir nos esforços de não só dar a todos educação, mas de dá-la cada vez melhor e mais extensa, assim me referi ao movimento, então, ao meu ver, indicativo de um processo inicial de unificação do povo brasileiro:

"Mas não teve, de logo, o serviço público de educação a presunção de poder assim se organizar, integralmente. O paulista, antes de tudo, não é um visionário. A sua imaginação, adestrada na realidade imediata de sua luta diária pela vida, não se entusiasma senãc pelos ideais praticáveis e exequíveis. Se um dos traços mais defini- 
dos por onde se pode caracterizar a escola paulista é um traço de idealismo - o de seu vigoroso espírito democrático, - nem por isso deixou a sua organização de se prender estritamente aos limites da sua possibilidade de execução.

"Êsse idealismo orgânico e construtor fêz com que aqui, primeiro que tudo, se buscasse dar a todos a oportunidade de freqüentar a escola. Fôsse preciso reduzir os cursos até o mínimo, não importava, contanto que se estendesse ao máximo o número de paulistas que por ela viessem a ser favorecidos."

A realidade, porém, é que o movimento não tinha essa sinceridade revolucionária. A educação do povo não era problema estrutural da nova sociedade brasileira em processo de demờratização, mas contingência que se tinha de remediar, de forma mais aparente do que real, e daí permanecer o nível aceitável como mínimo, na época, até hoje, antes agravado com os turnos e conseqüentes reduções de horário.

A estrutura fundamental de uma sociedade dual de senhores e dependentes, favorecidos e desfavorecidos, continuava viva e dominante e a funcionar pacificamente enquanto se pudesse conter o povo em suas reivindicações políticas de voto livre e secreto.

O voto livre e secreto, a real franquia eleitoral, é que viria destruir o ciualismo e tornar a educação não apenas uma liberalidade, mas necessidade invencível da organização social brasileira.

$\mathrm{E}$ a isto é que chegamos, depois de vinte e tantos anos de vicissitudes políticas de tôda ordem. Conquistou o povo brasileiro, afinal, a sua emancipação política. Pelo voto livre e secreto, constituem-se os pcderes da república, os poderes dos Estados, os poderes dos municípics. Como chegamos a essa conquista, sem escolas adequadas para a educação do povo, nem escolas adequadas para a formação - não de uma classe governante - mas dos múltiplos quadros médios e superiores de uma democracia de hierarquia ocupacional e não pròpriamente social, estamos a sofrer as consequiências melancòlicamente profetizadas por todos os teoristas da democracia. Que dizia, com efeito, CEsário MotTA em 1894?

"E que pràticamente ficou demonstrado o asserto, tão conhecido, do imortal americano: "A democracia sem a instrução será uma comédia, quando não chegue a ser tragédia." E que a República sem a educação inteligente do povo, poderia dar-nos, em vez do govêrno democrático, o despotismo das massas, em vez de ordem, a anarquia, em vez da liberdade, a opressão." (7)

E não é isso o que vemos? São por acaso poucos cs sinais de anarquia, de confusão, de falta de segurança e de falta de proporção, os sinais, enfim, de não estarmos preparados para os poderes que adquirimos?

(6) Discurso de ANísio TEIxeIra no encerramento do Congresso de Educação, em Säo Paulo, 1929.

(7) Cesário MOTTA, Secretário do Interior em 1894 - Discurso proferido quando da inauguração da Escola Normal da Praça da República. 
A nossa própria estrutura administrativa de estado, altamente centralizada, era perfeitamente lógica na sociedade dual que possuíamos. A União e os Estados representavam a parcela de poder confiada às "classes governantes", à minoria ou elite do país, cabendo-lhes a responsabilidade da vida nacional.

Com a chegada da democracia e a consciência de emancipação política atingida, afinal, pelo povo brasileiro, temos de repensar todos os nossos problemas de organização e, entre êles, o de educação.

Como, entretanto, em pleno tumulto econômico e político, assaltado por oportunidades de tôda ordem e com os quadros de direção ocupados pur elementos de uma geração formada sob a influência de negações à democracia e, por isto mesmo, sem a consciência perfeita das necessidades da nova ordem em vias de se estabelecer e, ainda mais, sem nenhuma experiência dos esforços feitos por outros povos para a realização de conquista semelhante?

\section{A REVOLUÇÃo E A CONTRA-REVOLUÇÃO DE 30 A 45}

A realidade é que, com a evolução política iniciada em 20 , contra tóda expectativa, tivemos uma paradoxal exaltação da tese de formação de elites. Com efeito, até a década de 20, tínhamos uma estrutura educacional, de certo modo, aceitável. Nessa década, talvez sem o querer conscientemente destruímos a escola primária com uma falsa teoria de alfabetização, reduzindo-lhe as séries. $\mathbf{E}$ na década seguinte, incentivamos uma educação secundária a partir dos onze anos, estritamente acadêmica e a ser ministrada, pelos particulares, mediante concessão do Estado. Destinada a quem? A todo o povo brasileiro? Por certo que não - pois a estrutura legal votada confiava à iniciativa particular a execução da reforma. Destinada, sim, a alargar a "classe governante".

A reforma educacional de 31 , no ensino secundário, longe de refletir qualquer ideal democrático, consolida o espírito de nossa organização duàlista de privilegiados e desfavorecidos. A escola secundária seria uma escola particular, destinada a ampliar a "classe dos privilegiados". Nenhum dos seus promotores usa a linguagem nem reflete a doutrina dos educadores democráticos.

A revolução de 30 , nascida das inquietações políticas e democráticas de 20, fêz-se logo, como vemos, reacionária e representou nos seus primeiros quinza anos uma reação contra a democracia. Apagou-se no país tôda ideo-ogia popular e mesmo o próprio senso da república, cabendo, por desgraça nossa, à geração formada nesse seríodo conduzir a experiência da democracia renascente em 46.

Essa geração nunca teve experiência sequer da doutrina democrática \& estava inocente da necessidade de educação para o estabelecimento da difusão de poder, que gera, inevitàvelmente, a democracia. Se entramos na república ainda marcados pela experiência escravagista, reiniciamos a república, marcados pela experiência totalitária. A experiência totalitária nada 
mais é do que o propósito de manter, pela violência, a estrutura dualista. das sociedades antidemocráticas, antes mantida por consentimento tácito.

Não deixou, assim, de ter a sua lógica a tentativa de conter a democracia no período de 37 a 45 . A sociedade brasileira, pelas suas fôrças dominantes, estaria lutando pela permanência de moldes tradicionais ou como tais aceitos; nem de outra forma se poderia explicar o vigor do Estado Novo e a sua sobrevivência ainda hoje, em muito do que sucede no país.

Se juntarmos ao vigor do tradicionalismo brasileiro assim renascido, o despreparo da geração hoje dominante no país para a própria ideologia democrática, teremos as duas razões circunstanciais que tornam tão difícil, em nossa atual conjuntura, configurar de forma lúcida e convincente o problema da formação democrática do brasileiro.

Às duas referidas circunstâncias veio ainda somar-se uma terceira e das mais importantes: a luta contra o comunismo, que se reabriu, logo após a segunda guerra mundial, durante a qual muitos chegaram a admitir certa atenuação, descontando-se a coexistência pacífica de dois mundos à parte... O caráter difuso da luta reaberta e quiçá exacerbada concorre para que dela se aproveitem certas fôrças reacionárias do capitalismo e do obscurantismo e se crie um clima pouco propício à afirmação do sentido revolucionário da democracia.

Dando a democracia como realizada, fàcilmente se pode fazer passar por comunismo todo e qua!quer inconformismo em face da situação existente ou qualquer desejo de mudança ou aperfeiçoamento, operando o alimentado conflito como um freio contra o desenvolvimento dos mais singelos postulados democráticos.

Se juntarmos, pois, repetimos, a nossa tradição autoritária e semifeudal, o movimento reacionário e fascista da década de 30 , no qual veio a se formar a geração atual brasileira, e a posiçâo retrátil e defensiva da democracia em virtude de sua luta contra o comunismo, após a segunda guerra mundial, teremos os motivos pelos quais se torna difícil a criação de uma vigorosa mentalidade democrática no Brasil.

Devido à atitude defensiva da democracia, na fase atual do mundo, perdemos o sentido de sua filosofia política e, cautelosamente, obscurecemos as reivindicações populares que ela envolve. E criada que seja essa atitude, abrimos o caminho para estreitas e egoísticas reivindicações pessoais.

A educação chega a se tornar, assim, não um campo de esforços pela realização de um ideal, mas um campo de exploração de vantagens para professôres e alunos.

Salários, redução de honorários, facilitação dos estudos e da obtenção de diplomas; expansão dessa dissolução, para a criação de novas oportunidades de salários e novas facilidades de ensino - são êstes os problemas, os graves problemas educacionais da hora presente.

Como fazer ressaltar, nesse clima, os autênticos e graves problemas da escola pública e da escola particular, da educação para o trabalho e da educação para o parasitismo, da educação "humanística" e da educação para a eficiência social, da educação para a descoberta e para a ciência e da educa- 
ção para as letras, da educação para a produção e da educação para o consumo? Em ambiente assim confinado, em que tudo já foi feito e o mundo já se acha construído, tôda a questão será apenas a de ampliar oportunidades já existentes para maior grupo de gozadores das delícias de nossa civilização.

Reacionarismo e conservadorismo parecem coisas inocentes, mas o seu preço é sempre algo de espantoso.

\section{COMO RESTAURAR O SENTIDO DEMOCRÁTICO DA EXPANSÃO EDUCACIONAL BRASILEIRA?}

Aceleração do processo histórico sob o impacto do progresso material, ignorância generalizada em virtude das deficiências e perversões do processo educativo e clima de conservadorismo senão reacionarismo social estão, assim, a criar, no país, condições particularmente difíceis à nossa ordenada evolução educacional.

A despeito de tudo isso ou, talvez, por isso mesmo, aqui estamos neste congresso, chamados exatamente para achar um caminho para as nossas dificuldades de educadores.

O primeiro passo não pode deixar de se analisar e definir a situação. E fci o que procuramos fazer, com as considerações que vimos desenvolvendo ante a vossa atenção generosa.

Se vale alguma coisa a análise que fizemos, temos de descobrir, baseados nela, os meios de corrigir e reorientar a situação, no sentido de revigorar certas fôrças e superar ou contrabalançar outras.

Não se pode negar o intenso dinamismo da situação presente do Brasil. Há um despertar geral das consciências individuais para novas oportunidades e há progresso material para atender, pelo menos em parte, a corrida a novos cargos e novas ocupações. Como inserir nesse processo dinâmico de mudança o fator educação, de modo que êle ajude, estimule e aperfeiçoe tôda a transformação, dando-lhe quiçá novos ímpetos e melhor segurança de desenvolvimento indefinido?

Temos, primeiro que tudo, de restabelecer o verdadeiro conceito de educação, retirando-lhe todo o aspecto formal, herdado de um conceito de escolas para o privilégio e, por isto mesmo, reguladas apenas pela lei e por tôda a sua parafernalia formalística, e caracterizá-la, enfàticamente, como um processo de cultivo e amadurecimento individual, insuscetível de ser burlado, pois corresponde a um crescimento orgânico, humano governado por normas científicas e técnicas, e não jurídicas, e a ser julgado sempre a posteriori e não pelo cumprimento formal de condições estabelecidas a priori.

Restabelecida esta maneira de conceituá-la, a educação deixa de ser o campo de arbitrária regulamentação legal, que no Brasil vem fazendo dela um objeto de reivindicação imediata, por intermédio do miraculoso reconhecimento legal ou oficial. O fato de havermos confundido e identificado o processo educativo com um processo de formalismo legal levou a educação a ser julgada por normas equivalentes às da processualística judiciária que é, 
essencialmente, um regime de prazos e de formas, fixados, de certo modo, por convenção.

Ora, se o processo educativo é fixado por convenção, está claro que a lei pode mudar as convenções... E daí a poder decretar educação é um passo. E que outra coisa temos feito, desde os repetidos espetáculos maiores dos exames por decreto, senão dar e tornar a dar êste passo?

Tôda a nossa educação, hoje, é uma educação por decreto, uma educação que, para valer, sòmente precisa de ser "legal", isto é, "oficial" ou "oficializada". E pela lei que a escola primária de três e quatro turnos é iǵual à escola primária completa, que o ginásio particular ou público, sem professôres nem condições para funcionar, é igual aos melhores ginásios do país, que a escola superior improvisada, sem prédios nem professôres, é igual a algumas grandes e sérias escolas superiores do país.

A primeira modificação ${ }^{3}$ é, pois, esta: educação, como agricultura, como medicina, não é algo que se tem de regular por normas legais e que só delas dependa, mas processo especializado, profissional, extremamente variado, em velocidade e em perfeição, e que deve ser aferido por meio de outros processos especializados, sujeitos ao delicado arbitrio de profissionais e peritos e não a meras regras legais ou regulamentares, aplicáveis por funcionários.

A legislação sôbre educação deverá ter as características de uma legislação sôbre a agricultura, a indústria, o tratamento da saúde, etc., isto é, uma legislação que fixe condições para sua estimulação e difusão, e indique mesmo processos recomendáveis, mas não pretenda definí-los, pois a educação, como o cultivo da terra, as técnicas da indústria, os meios de cuidar da saúde não são assuntos de lei, mas da experiência e da ciência.

Fixado que seja o critério de que a lei não faz, não cria a educação, desaparecerá a corrida junto aos poderes públicos para equiparar, reconhecer e oficializar a educação, a fim de que valha ela, independente de sua eficiência e dos seus resultados, e assim se extinguirá um dos meios de identificar a educação com a simples aquisição de vantagens e privilégios, mediante o cumprimento de formalidades.

- Quem, porém, julgará os resultados da educação?

- Os próprios professôres, pelos processos reconhecidos, pela experiência e pela ciência, para se fazerem tais avaliações.

Apenas, os seus julgamentos, ao medir e apreciar o processo de educação elaborado sob a sua direção, nunca poderão ter o valor de sentenças passadas em julgado em instância suprema. Para valer para terceiros, isto é, para outras escolas ou para agências empregadoras, sejam privadas ou públicas, não há como não permitir novo exame, por professôres outros que não os que ensinaram e educaram. Por outras palavras, o diploma escolar é uma presunção de preparo e não um atestado de preparo. Pode ser aceito ou não, nunca se negando à instituição que receba o aluno para a continuação dos estudos, ou que o deseje empregar, ou que o vá autorizar a exercer qualquer profissão, o direito a reexaminar o candidato e, à luz do que souber, confirmar-lhe ou negar-lhe a competência presumida. 
A transferência para a consciência profissional dos professôres ou educadores, do poder de orientar a formação escolar, dentro das autorizações amplas da lei, não se poderá fazer sem retirar aos diplomas escolares a falsa liquidez que, hoje, se the atribui.

Dir-se-á que o Brasil não tem condições para gozar dessa liberdade, que os professôres não têm competência para decidir sôbre o que ensinar nem como ensinar, etc., etc. Ora, se assim fôr, pior é que o possa fazer com a sanção oficial. $O$ que desejamos é dar-lhes liberdade para que o façam do melhor modo que seja possível e os julguemos depois pelos resultados.

A lei estabelecerá os períodos de educação elementar, complementar, média ou secundária, e superior, definirá os grandes tipos e espécies de educação e facultará a sua organização, no âmbito oficial e na esfera particular.

Na sua existência real, as escolas constituirão um universo, a ser julgado por processos de classificação profissional, semelhantes aos que servem ao julgamento - permitam que o repita - de hospitais e casas de saúde, de campos e granjas agrícolas, de fábricas e conjuntos industriais, etc., etc.

Năo basta, porém, a mudança de conceito da escola para o de instituição profissional e não apenas legal. E necessário, já agora, em vista da sua intenção de promover a democracia, que ela seja, no campo da educação comum, para todos, dominantemente pública.

Não advogamos o monopólio da educação pelo Estado, mas julgamos que todos têm direito à educação pública, e sòmente os que o quiserem é que poderão procurar a educação privada.

Núma sociedade conı a nossa, tradicionalmente marcada de profundo espírito de classe e de privilégio, sòmente a escola pública será verdadeiramente democrática e sòmente ela poderá ter um programa de formação comum, sem os preconceitos contra certas formas de trabalho essenciais à democracia.

Na escola pública, como sucede no exército, desaparecerão as diferenças de classe e todos os brasileiros se encontrarão, para uma formação comum, igualitária e unificadora, a despeito das separaçốes que vão, depois, ocorrer.

Exatamente porque a sociedade é de classes é que se faz ainda mais necessário que as mesmas se encontrem, em algum lugar comum, onde os preconceitos e as diferenças não sejam levados em conta e se crie a camaradagem e até a amizade entre os elementos de uma e outra. Independente da sua qualidade profissional e técnica, a escola pública tem, assim, mais esta função de aproximação social e destruição de preconceitos e prevenções. A escola pública não é invenção socialista nem comunista, mas um daqueles singelos e esquecidos postulados da sociedade capitalista e democrática do século dezenove.

Já todos estamos vendo que escola pública não é escola cujo programa e currículo sejam decididos por lei, mas, simplesmente, escola mantida com recursos públicos. 
Por ser mantida com recursos públicos, não irá porém, transformar-se em repartição pública e passar a ser gerida, como se fôsse uma qualquer dependência administrativa ou do poder estatal.

Em qualquer das democracias de tipo anglo-saxônico, a diferença entre professor público e funcionário é perfeitamente marcada. Não sòmente têm estatutos diferentes, como têm estilos, maneiras e modos de ser diferentes. Se me fôsse permitida uma comparação, diria que entre o funcionário civil e o professor público haveria diferença equivalente à que existe entre aquêle e o militar.

Bem sei que também nós admitimos certas diferenças, mas a tendência vem sendo a de uniformizar todos os servidores do Estado. E esta é uma das tendências a combater.

Dentro do espírito de escola como instituição profissional, a escola, quando pública, faz-se șuma instituição pública especial, gozando de autonomia diversa da de qualquer pura e simples repartição oficial, pois a dirigem e servem profissionais específicos, que são mais profissionais do que funcionários públicos.

Daí defender eu a administração autônoma das escolas de nível médio e superior e a administração central das escolas de nível elementar. Sòmente às escolas elementares aconselharia a administração central, não, porém, de um centro remoto, mas, da sede do município, enquanto não podemos chegar à sede distrital.

Faz-se confusão com o que venho chamando municipalização do ensino primário. Julgo, em nosso regime constitucional, a educação uma função dos Estados, sujeitos êstes tão só à lei de bases e diretrizes da União - espécie de constituição para a educação em todo o país. A administração local, que propugno para as escolas elementares, e a autonomia das escolas médias não importam em nenhuma subordinação do ensino pròpriamente a qualquer soberania municipal, mas em um plano de cada Estado de confiar a administração das escolas a órgãos locais, subordinados êstes ao Estado pela formação do magistério, que a êle Estado competiria, privativamente, e pelo custeio das escolas, pois, a quota-aluno com que contribuiria o Estado seria, em quase todos os casos, superior à quota-aluno municipal, importando isto, sem dúvida, na possibilidade de contrôle que os Estados julgassem necessário.

O Estado é que confiaria a órgãos locais, previstos na lei orgânica dos municípios ou numa lei orgânica de educação, a administração, - por motivos de expediente, pois o órgão local seria mais eficiente do que o órgão estadual, distante na gerência da escola; por motivos sociais, pois assim melhor se caracterizaria a natureza local da instituição e o seu enraizamento na cultura local; e ainda por motivos econômicos, pois isto permitiria a adaptação da escola aos níveis econômicos locais.

A nova escola pública, de administração municipal, ou autônoma, não deixaria, assim, de ser estadual - pelo professor, formado e licenciado pelo Estado, embora nomeado pelo órgão local, pela assistência técnica e pelo livro didático e material de ensino, elaborados sem dúvida no âmbito do 
Estado em seu conjunto. E, permitam-me ainda dizer, não deixaria de ser federal - pela obediência à lei nacional de bases e diretrizes e, ainda, talvez, pelo auxílio financeiro e a assistência técnica que os órgãos federais the viessem a prestar.

Julgo que a nossa maquinaria administrativa centralizada para a direção das escolas é um dos resíduos do período dualístico de nossa sociedade, sempre a julgar que sòmente certa elite seria capaz de governar e dirigir, elite esta que se entrincheiraria tanto nos quadros estaduais como nos federais.

De qualquer modo, porém, o plano que propugno, em nenhum ou por nenhum dos seus aspectos, impede que as possiveis elites estaduais ou federais continuem a exercer a sua influência, praza aos céus que salutar!

\section{RESULTADOS DESSA RECUPERAÇÃO DEMOCRÁTICA}

Com tais alterações, aparentemente simples, mas do mais largo alcance, desejaríamos, como acentuamos, fortalecer algumas tendências e corrigir outras da nossa expansão educacional.

a) Fortaleceríamos o desejo de oportunidades educacionais, facultando a organização de escolas na medida das fôrças locais, a serem julgadas pelo seu mérito, mediante sistema de "classificação" a posteriori.

b) Libertaríamos, assim, a escola das rígidas prisões legais que convidam à fraude, e estimularíamos as iniciativas honestas e sérias, estabelecendo uma ampla equivalência entre os diversos tipos de escola, baseada no número de anos de estudos e nos resultados obtidos ou eficiência demonstrada, mais no sentido de amadurecimento intelectual e social do que de identidade das informações adquiridas.

c) Incentivariamos o estudo da educação, nos seus múltiplos e diversos aspectos, já que não haveria modelos uniformes e rígidos a seguir e teriam todos liberdade e responsabilidade no que viessem a empreender e efetivamente realizar.

d) Abandonariam diretores, professôres e alunos a corrida por vantagens pessoais de tôda ordem, pois o ensino deixaria de ser oportunidade para exercício de habilidades e simulações para se tornar um trabalho, interessante por certo, mas sujeito às leis severas do seu próprio sucesso.

e) Ajustaríamos as escolas às condições locais, sendo de esperar que se transformassem em motivo de emulação e orgulho das comunidades a que servem e que, a seu turno, thes dariam apoio estimulante.

f) Pela descentralização e autonomia, daríamos meios eficazes para a administração mais eficiente das escolas e responsabilidade dignificante a diretores e professôres, que não estariam trabalhando em obediência a ordens distantes, mas sob a inspiração dos seus próprios estudos e competência profissional.

B) A flexibilidade necessàriamente impressa ao processo educativo melhor o aparelharia para atender às diferenças individuais, inclusive quanto à marcha da aprendizagem dos alunos e à verificação dessa aprendizagem. 
h) Os órgãos estaduais e federais, libertos dos deveres de administração das escolas, poderiam entregar-se ao estudo dos sistemas escolares e dar às escolas melhor assistência técnica, atuando para a sua homogeneidade pela difusão dos melhores métodos e objetivos, cuja adoção promovessem por persuasão e consentimento, e não por imposição.

Em suma, as medidas aqui sugeridas e outras, que possam ser propostas, se destinariam a aumentar e até fortalecer, mais ainda, se possível, o ímpeto atual da expansão escolar brasileira, impedindo-a, ademais, de se fazer um movimento de dissolução, com o retirar-lhe tôda e qualquer vantagem ilegítima ou antecipadamente garantida, submetendo todo o processo educativo ao teste final dos resultados.

A lei de bases e diretrizes que o Congresso Nacional terá de votar fixaria as linhas gerais do sistema escolar brasileiro, contínuo e público, com uma escola primária de seis anos, uma escola média de sete ou cinco, conforme incorporasse, ou não os dois anos complementares da escola primária de seis, o colégio universitário e o ensino superior. E, concomitantemente, se cuidaria de evitar que continuassem estanques ou sem oportunidades de equivalência e transferências as escolas de grau médio com caráter especializado, profissional, qualquer que fôsse.

Com a administração local, ou autônoma, por instituição, quando médias ou superiores - as escolas do Brasil seriam um grande universo diversificado e em permanente experimentação, podendo sempre melhorar, vivificado pela liberdade e responsabilidade de cada pequeno sistema local ou de cada instituição, e a buscar, pela assistência técnica do Estado e da União, atingir gradualmente a unidade de objetivos e a equivalência de nível, sem perda das características locais, pela própria qualidade do ensino ministrado.

Abusos e erros, por certo, continuariam a existir, mas sem o horror da assegurada sanção oficial e, por serem de responsabilidade pessoal e local, sempre limitados ou não generalizados e com a possibilidade de se corrigirem, senão espontâneamente, pelo menos graças ao jôgo de influências exercidas pela assistência técnica, sôbre os serviços locais de educação.

Resta o mais difícil: os recursos financeiros.

Criada a consciência da necessidade de educação, esclarecido o seu caráter de reivindicação social por excelência, acredito que não fôsse difícil a criação, com as percentagens previstas na Constituição, dos fundos de educação municipais, estaduais e federal. Tais fundos, administrados autônomamente, iriam dar o mínimo de recursos, que o próprio êxito dos serviços educacionais faria crescer cada vez mais. (8)

A sua distribuição inteligente iria, de qualquer modo, permitir o crescimento gradual dos sistemas escolares, transformados nos serviços maiores das comunidades, contando com o concurso de fôrças locais, fôrças estaduais e fôrças federais para o seu constante desenvolvimento.

(8) Vide "Como Financiar a Educação". ANísıo TEIXEIrA, in A Educação e a Crise Brasileira. Comp. Editôra Nacional, S. Paulo. 


\section{ESCOLA PÚBLICA, UNIVERSAL E GRATUITA}

Não desejo terminar a análise e o apêlo que esta palestra encerra ou significa, sem uma palavra mais direta sôbre a escola primária, embora estivesse ela, explícita ou implìcitamente, sempre presente no meu pensamento e em tôdas as palavras até aqui proferidas, pois ela é o fundamento, a base da educação de tôda a nação. Dela é que depende o destino ulterior de tôda a cultura de um povo moderno. Se de outras se pode prescindir e a algumas nem sempre se pode atingir, ninguém dela deve ser excluído, sob qualquer pretexto, sendo para todos imprescindível. Façamo-la já, de todos e para todos.

Em épocas passadas, a cultura de um país podia basear-se em suas universidades. As civilizações fundadas em elites cultas e povos ignorantes prescindiram da escola primária. As sociedades constituídas por privilegiados e multidões subjugadas também sempre prescindiram da cultura popular.

As democracias, porém, sendo regimes de igualdade social e povos unificados, isto é, com igualdade de direitos individuais e sistema de govêrno de sufrágio universal, não podem prescindir de uma sólida educação comum, a ser dada na escola primária, de currículo completo e dia letivo integral, destinada a preparar o cidadão nacional e o trabalhador ainda não qualificado e, além disto, estabelecer a base igualitária de oportunidades, de onde irão partir todos, sem limitações hereditárias ou quaisquer outras, para os múltiplos e diversos tipos de educação semi-especializada e especializada, ulteriores à educação primária.

Nos países econômicamente desenvolvidos, até a educação média, imediatamente posterior à primária, está se fazendo também comum e básica. $\mathrm{E}$ a tanto também nós tendemos e devemos mesmo aspirar.

Por enquanto, porém, apenas podemos pensar na educação primária, como obrigatória, já estendida, contudo, aos seis anos, o mínimo para uma civilização que, começa a industrializar-se.

A educação comum, para todos, já não pode ficar circunscrita à alfabetização ou à transmissão mecânica das três técnicas básicas da vida civilir zada - ler, escrever e contar. Já precisa formar, tão sòlidamente quanto possível, embora em nível elementar, nos seus alunos, hábitos de competência executiva, ou seja eficiência de ação; hábitos de sociabilidade, ou seja interêsse na companhia de outros, para o trabalho ou o recreio; hábitos de gôsto, ou seja de apreciação da excelência de certas realizações humanas (arte); hábitos de pensamento e reflexão (método intelectual) e sensibilidade de consciência para os direitos e reclamos seus e de outrem - - V. JoHN DEWEY, Democracy and Education (trad. bras. da Comp. Editôra Nacional).

Vejam bem que não se insiste na quantidade de informação (instrução) que a escola primária vá dar ao seu aluno; mas, por outro lado, o que se the pede é muito mais do que isto. Daí, o corolário imperioso: sendo a 
escola primária a escola por excelência formadora, sobretudo porque não estamos em condições de oferecer a tôda a população mais do que ela, está claro que, entre tôdas as escolas, a primária, pelo menos, não pode ser de tempo parcial. Sòmente escolas destinadas a fornecer informações ou certos limitados treinamentos mecânicos podem ainda admitir o serem de tempo parcial.

A escola primária, visando, acima de tudo, a formação de hábitos de trabalho, de convivência social, de reflexão intelectual, de gôsto e de consciência não pode limitar as suas atividades a menos que o dia completo. Devem e precisam ser de tempo integral para os alunos e servidas por professôres de tempo integral.

Este congresso não se deveria encerrar sem uma solene declaração de princípios, em que o professorado paulista tomasse sôbre os ombros a responsabilidade de promover a recuperação da escola primária integral para São Paulo e dar o sinal para a mesma recuperação em tôdo o país, redefinindolhe os objetivos, os métodos e a duração, e traçando o plano para a sua efetivação.

A escola primária de seis (6) anos, em dois ciclos, o elementar de 4 e o complementar de 2, com seis horas mínimas de dia escolar, 240 dias letivos por ano e professôres e alunos de tempo integral, isto é, proibidos de acumular com a função de ensino qualquer outra ocupação, que não fôsse estritamente correlativa com o seu mister de professor primário, êstes seriam os alvos a atingir, digamos, dentro de cinco anos.

Um alvo suplementar, mas igualmente indispensável, seria o da formação do magistério, tornando-se obrigatório que, dentro dos cinco anos do plano, pelo menos um décimo $(1 / 10)$ do professorado primário tivesse a sua formação completada com dois anos de estudos, em nível superior. Por outras palavras, a formação do magistério primário se faria, em duas etapas, a atual de nível médio, para o início da carreira, e dois anos complementares, de nível portanto superior, para a sua continuação em exercício, depois de cinco anos probatórios. Esses dois anos de estudo se fariam ou em cursos regulares de férias, ou, pelo afastamento do exercício, dentro dos cinco anos iniciais, em cursos regulares. De sorte, que, tão depressa quanto possível, pudesse o professorado contar, em cada nove professôres de formação média, com um de formação superior, que, como supervisor, os assistisse e guiasse, nos variados trabalhos escolares.

Estas, as etapas mínimas a serem conquistadas no plano qüinqüenal para a educação primária, que aqui poderia ser apresentado, como o plano de Ribeirão Prêto ou plano de São Paulo.

Não me direis que faltam recursos para tal plano, em um país cujos aumentos de salários orçam por dezenas de bilhões de cruzeiros. Faltará, talvez, prioridade para as despesas necessárias, e só isto. Não será, porém, uma tal prioridade a que deve ser, a que vai ficar definida no Congresso, para 
cujos componentes e à margem de cujas deliberações, estou tendo a honra de falar?

A declaração que aqui se deverá fazer será uma declaração de consciência profissional, pela qual o magistério primário de São Paulo, desprendendo-se de reivindicações até agora excessivamente limitadas, afirmará à Nação e ao Estado, em tôda a sua amplitude, as condições educacionais em que poderá trabalhar, para conduzir a maior tarefa que um povo, uma nação, pode distribuir a um corpo de seus servidores: a da formação básica do brasileiro, para a sua grande aventura social de construção do Brasil.

Não desmerecemos nenhum dos esforços para a educação ulterior à primária, mas reivindicamos a prioridade número um à escola de que dependem tôdas as escolas - a escola primária. 